\title{
Determining the absolute configuration of vanitaracin $A$, an anti-hepatitis $B$ virus agent
}

\author{
Shinji Kamisuki $\circledast^{1,2} \cdot$ Hisanobu Shibasaki ${ }^{1}$ Koudai Ashikawa ${ }^{1} \cdot$ Kazuki Kanno ${ }^{1} \cdot K^{2}$ Koichi Watashi ${ }^{3,4} \cdot$ \\ Fumio Sugawara $^{4} \cdot$ Kouji Kuramochi $^{4}$
}

Received: 2 September 2021 / Revised: 10 November 2021 / Accepted: 28 November 2021 / Published online: 16 January 2022

(c) The Author(s), under exclusive licence to the Japan Antibiotics Research Association 2021

\begin{abstract}
Vanitaracin A is an anti-hepatitis B virus (anti-HBV) compound isolated from the culture broth of the fungus Talaromyces sp. Vanitaracin A inhibits the entry of HBV into target cells with sub-micromolar $\mathrm{IC}_{50}$ values. While a structure-activity relationship study is highly desirable, a synthetic approach still needs to be developed, which is difficult because the absolute configurations of the six stereogenic centers in the structure of vanitaracin A have not yet been determined. In the present study, we used the crystalline sponge method to clarify the configuration of the compound after determining the absolute configuration of the secondary alcohol using a modified Mosher ester method. Combining these analyses with the NOESY spectrum of vanitaracin A and NMR analyses of the crude side-chain carboxylic acid obtained by the alkaline hydrolysis of vanitaracin A revealed the absolute configurations of all stereogenic centers in this important compound.
\end{abstract}

\section{Introduction}

Sustained hepatitis B virus (HBV) infections can cause chronic liver diseases, such as liver cirrhosis and hepatocellular carcinoma. According to the World Health Organization (WHO), 296 million people worldwide were chronically infected, and 820,000 deaths were caused by cirrhosis or hepatocellular carcinoma in 2019 [1]. Small molecule drugs clinically used to treat chronic HBV infection include nucleos(t)ide analogs, such as entecavir

Supplementary information The online version contains supplementary material available at https://doi.org/10.1038/s41429021-00496-1.

$\triangle$ Shinji Kamisuki

kamisuki@azabu-u.ac.jp

1 School of Veterinary Medicine, Azabu University, Fuchinobe, Sagamihara, Kanagawa 252-5201, Japan

2 Center for Human and Animal Symbiosis Science, Azabu University, Fuchinobe, Sagamihara, Kanagawa 252-5201, Japan

3 Research Center for Drug and Vaccine Development, National Institute of Infectious Diseases, 1-23-1 Toyama, Shinjuku-ku, Tokyo 162-8640, Japan

4 Department of Applied Biological Science, Tokyo University of Science, Yamazaki, Noda, Chiba 278-8510, Japan and tenofovir, which inhibit reverse transcription [2, 3]. Although nucleos(t)ide analogs reduce the risk of developing hepatocellular carcinoma, long-term treatment with nucleos(t)ide analogs often results in the emergence of drug-resistant viruses and lower treatment efficacies [4-6]. To overcome this problem, novel anti-HBV agents aimed at different molecular targets need to be developed.

We previously isolated several antiviral natural products from the culture broths of fungi isolated from seaweed, mosses, and plants [7-12]. Neoechinulin B [7], sulochrin [8] (known compounds) and peniciherquamide $\mathrm{C}$ (a novel compound) [9] were found to inhibit hepatitis $\mathrm{C}$ virus (HCV) infection. In addition, we discovered that vanitaracin A, a novel tricyclic polyketide, is an anti-HBV agent (Fig. 1) [10]. Vanitaracin A inhibits the viral entry process with an $\mathrm{IC}_{50}$ value of $0.61 \mu \mathrm{M}$ without evident cytotoxicity $\left(\mathrm{CC}_{50}>256 \mu \mathrm{M}\right)$ in primary human hepatocytes. Our mechanistic study revealed that vanitaracin A directly binds to sodium taurocholate co-transporting polypeptide (NTCP), an HBV entry receptor. Importantly, vanitaracin A was also effective against infection by a clinically relevant entecavir-resistant HBV strain [13].

The development of a synthetic approach to vanitaracin A and its derivatives is required to support a structure-activity relationship study; however, vanitaracin A possesses six stereogenic centers and only the syn $\mathrm{OH}-2 /$ $\mathrm{H}_{3}-15$ relationship was determined from NOESY 


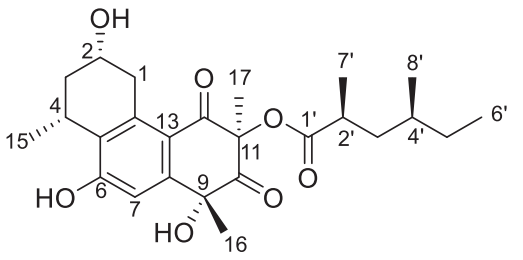

Fig. 1 Structure of vanitaracin A (1)
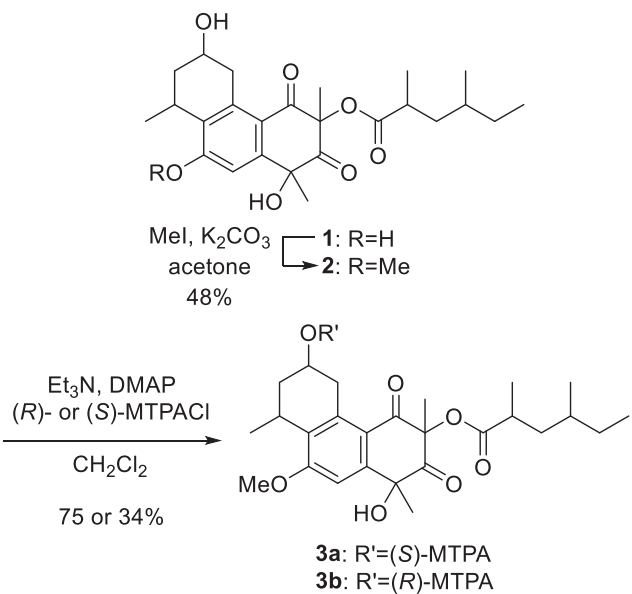

Scheme 1 Preparing $(S)$ - and (R)-MTPA esters 3a and $\mathbf{3 b}$ via methyl ether 2

correlations between $\mathrm{H}-2$ and $\mathrm{H}-4$ in our previous study [10]. In the present study, we determined the absolute configuration of the secondary alcohol in vanitaracin A using a modified Mosher ester method. Since vanitaracin A is difficult to crystallize, we used the crystalline sponge method to determine the relative configurations of the stereogenic centers in the compound. The crystalline sponge method is an X-ray technique that analyzes the structure of a compound by absorbing the guest compound into the ordered cavity of a crystalline porous metal-organic coordination complex [14]. In addition to these analyses, NOESY experiments on vanitaracin A and NMR analyses of the crude side-chain carboxylic acid obtained by the alkaline hydrolysis of vanitaracin A revealed the absolute configurations of all six of its stereogenic centers.

\section{Results and discussion}

We previously determined the syn $\mathrm{OH}-2 / \mathrm{H}_{3}-15$ relationship in vanitaracin $\mathrm{A}$ from the NOESY correlation between $\mathrm{H}-2$ and $\mathrm{H}-4$ [10]. To determine the absolute configuration at C-2, we synthesized the $\alpha$-methoxy- $\alpha$-trifluoromethylphenylacetic acid (MTPA, Mosher) ester of $\mathbf{1}$ (Scheme 1). To that end, 1 was reacted with methyl iodide in the presence of $\mathrm{K}_{2} \mathrm{CO}_{3}$ to yield methyl ether 2 , which was esterified with $(R)$ - or $(S)$ MTPA chloride to afford $(S)$ - or $(R)$-MTPA ester $\mathbf{3 a}$ or $\mathbf{3 b}$. Differences in the ${ }^{1} \mathrm{H}$ NMR chemical shifts of the two esters

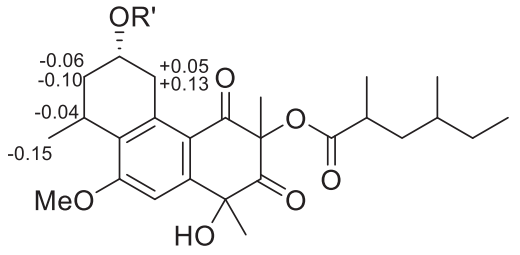

3a: $\mathrm{R}^{\prime}=(S)-M T P A$

3b: $\mathrm{R}^{\prime}=(R)-\mathrm{MTPA}$

Fig. $2 \Delta \delta$ values for MTPA esters $\mathbf{3 a}$ and $\mathbf{3 b}$

$\left(\Delta \delta ; \delta_{(S)}-\delta_{(R)}\right)$ revealed the absolute configuration at $\mathrm{C}-2$ to be $S$ (Fig. 2).

We used the crystalline sponge method to determine the configurations of the remaining stereogenic centers in vanitaracin A [14]. A single crystal of the porous $\left[\left(\mathrm{ZnI}_{2}\right)_{3}\right.$ $(\text { tpt })_{2}$ (solvent) $\left.)_{\mathrm{x}}\right]_{\mathrm{n}}$ complex (crystalline sponge, tpt, tris $(4-$ pyridyl)-1,3,5-triazine) was treated with vanitaracin A (1), which was absorbed into the crystal by the slow evaporation method $[14,15]$ and subjected to X-ray diffractometry. The structure of an asymmetric unit containing $\mathbf{1}$ and the crystalline sponge is shown in Fig. 3a. The relative configurations of $\mathrm{C}-2, \mathrm{C}-4, \mathrm{C}-11$, and $\mathrm{C}-2^{\prime}$ were determined as shown in Fig. 3b, which suggests that the absolute configuration of 1 is $2 S, 4 R, 11 R, 2^{\prime} S$. Unfortunately, we were unable to determine the configuration of C-9 using this method because $\mathrm{C}-16$ and $9-\mathrm{OH}$ are not distinguishable in the crystal structure. In addition, C-5' and C- $8^{\prime}$ were not distinguishable because the position of $\mathrm{C}-6^{\prime}$ was unclear owing to the various conformations of the side chain moiety; consequently, we were also unable to determine the configuration of C- $4^{\prime}$. To determine the configurations of C-9 and C-4', we subjected 1 to NOESY spectroscopy and analyzed the crude carboxylic acid obtained by the hydrolysis of $\mathbf{1}$ by NMR spectroscopy.

Recently, Chen et al. reported the structures of penijanthinones $\mathrm{A}$ and $\mathrm{B}$ that possess 2,4-dimethyl-4-hydroxycyclohexane-1,3-dione rings (Fig. 4a) [16]. They concluded that the two methyl groups in each structure are positioned on opposite faces of the ring because the relevant protons $\left(\mathrm{H}_{3}-16\right.$ and $\left.\mathrm{H}_{3}-17\right)$ are not NOE correlated. The NOESY spectrum of vanitaracin $A$ was acquired to reveal the configuration of C-9. No cross peaks were observed between $\mathrm{H}_{3}-16\left(\delta_{\mathrm{H}} 1.71\right)$ and $\mathrm{H}_{3}-17$ $\left(\delta_{\mathrm{H}} 1.50\right)$ (Fig. $4 \mathrm{a}$ and $\mathrm{S} 3$ ), suggesting that the relative configurations of the two methyl groups are similar to those of penijanthinones $\mathrm{A}$ and $\mathrm{B}$; hence, the absolute configuration of C-9 was assigned to be $R$. In addition, we acquired the electronic circular dichroism (ECD) spectrum of 1 (Fig. S4), which shows a negative Cotton effect at $296 \mathrm{~nm}$ and a positive Cotton effect at $245 \mathrm{~nm}$, which is similar to the calculated ECD spectra of the $9 R, 11 R$-isomers of penijanthinone A [16]. 
Fig. 3 Crystal structure of the complex of $\mathbf{1}$ and the crystalline sponge. (a) Asymmetric unit containing $\mathbf{1}$ and the crystalline sponge (ORTEP drawing with $50 \%$ probability). (b) Crystal structure of $\mathbf{1}$ in ball-and-stick representation. (c) Absolute structure of $\mathbf{1}$ determined by crystalline sponge analysis

a

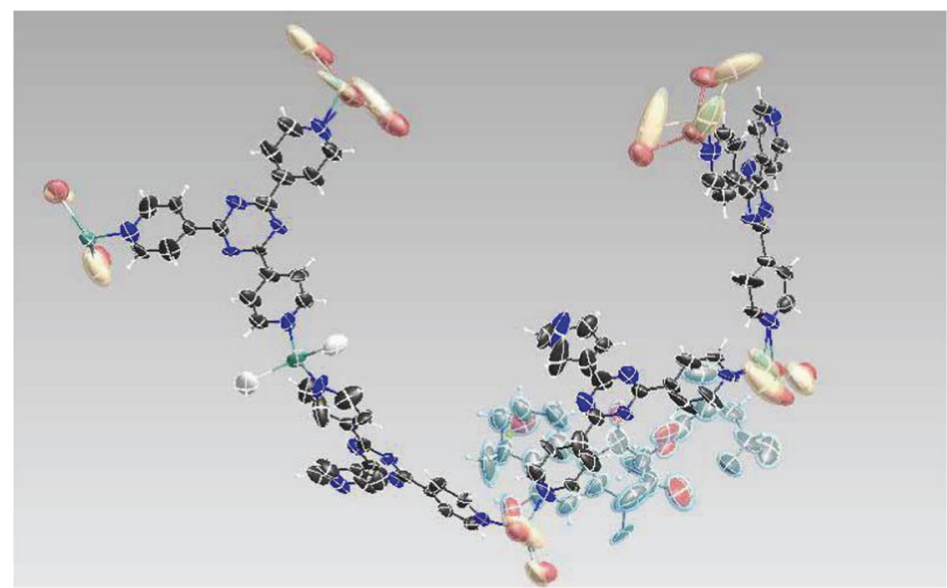

b

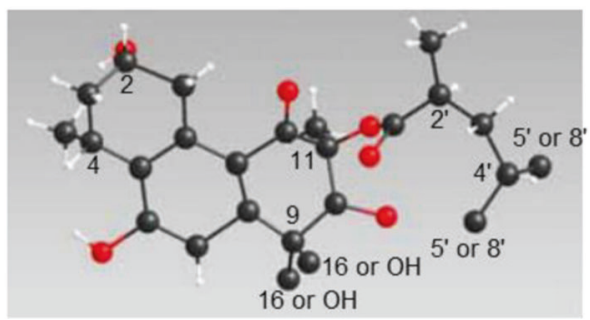

C

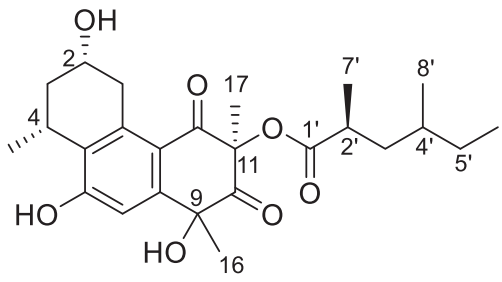

We compared the ${ }^{13} \mathrm{C}$ chemical shifts of the 2,4-dimethylhexanoate unit in $\mathbf{1}$ with literature values for $(2 R, 4 S)$ 2,4-dimethylhexanoic acid and (2S,4S)-2,4-dimethylhexanoic acid (Table 1) to determine the configuration of C- $4^{\prime}$ [17]. The chemical shifts of $\mathbf{1}$ are almost identical to those of $(2 S, 4 S)$-2,4-dimethylhexanoic acid, whereas a difference was noted between the shift assigned to $\mathrm{C}-7^{\prime}$ in $\mathbf{1}(\delta$ 17.8) and that of the analogous carbon in $(2 R, 4 S)$-2,4-dimethylhexanoic acid ( $\delta$ 16.9) (underlined in Table 1). In addition, $\mathrm{H}-3^{\prime}$ in $\mathbf{1}$ exhibits a ${ }^{1} \mathrm{H}$ chemical shift that is in good agreement its counterpart in $(2 S, 4 S)$-2,4-dimethylhexanoic acid (Fig. 4b). Furthermore, 1 was hydrolyzed with $\mathrm{NaOH}$ to generate 2,4-dimethylhexanoic acid, and the crude extract was directly analyzed using ${ }^{1} \mathrm{H}-{ }^{1} \mathrm{H}$ COSY spectroscopy (Fig. 4c), which revealed that $\mathrm{H}-2$ in the carboxylic acid resonates at $1.73 \mathrm{ppm}$, identical to that reported for the $2 S, 4 S$-isomer. Based on these results, we propose that vanitaracin A has the $2^{\prime} S, 4^{\prime} S$ configuration. Schmidt et al. reported a ${ }^{1} \mathrm{H}$ NMR method for assigning the relative configuration of a 1,3-dimethylalkyl chain [18]. This method is based on the difference in the chemical shifts $(\Delta \delta)$ of the geminal methylene protons located between the two stereogenic centers. The relative configuration is anti when $\Delta \delta$ lies between 0.0 and $0.1 \mathrm{ppm}$, and is syn when $\Delta \delta>0.4$ $\mathrm{ppm}$. The difference in the chemical shifts $(\Delta \delta)$ of the C- $3^{\prime}$ geminal protons of vanitaracin A was determined to be 0.58 ppm (>0.4 ppm), which suggests a syn relationship (Fig. 4b). Hence, we conclude that vanitaracin $\mathrm{A}$ has the $2 S, 4 R, 9 R, 11 R, 2^{\prime} S, 4^{\prime} S$ absolute configuration.

In summary, in this study we revealed the absolute configuration of each stereogenic center in vanitaracin A, which will further stimulate research into vanitaracin A and related natural products. The synthesis of vanitaracin A is expected to lead to the identification of more potent analogs and the development of novel anti-HBV agents. In this study, we determined configurations by combining the crystalline sponge method and NMR spectroscopy. Similar combinational methods have already been used to determine structures and configurations and are becoming standard in the field [19-21].

\section{Materials and methods}

\section{General experimental procedure}

Optical rotations were recorded on a JASCO P-2200 digital polarimeter (Jasco Corp., Tokyo, Japan) at room temperature. ECD spectra were recorded in $\mathrm{MeOH}$ at a concentration of $1.0 \times 10^{-4} \mathrm{M}$ and $23^{\circ} \mathrm{C}$ using a JASCO J-820 CD spectrometer with 5-mm path-length quartz cuvettes. UV spectra were obtained using a UVmini-1240 spectrophotometer 
(Shimadzu Corp., Kyoto, Japan). Infrared (IR) spectra were recorded on a JASCO FT/IR-4600 spectrophotometer (Jasco

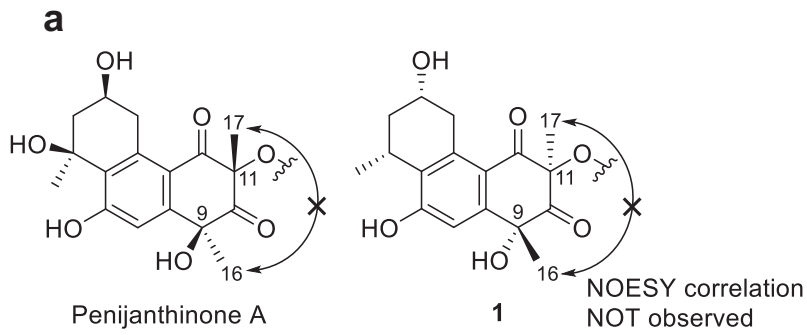

b

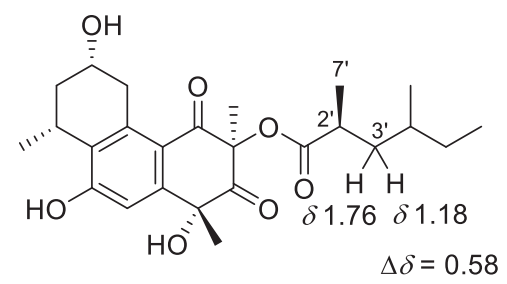<smiles>CCC(C)CC(C)C(=O)O</smiles>

$(2 R, 4 S)-2,4-\quad(2 S, 4 S)-2,4-$ dimethylhexanoic acid dimethylhexanoic acid

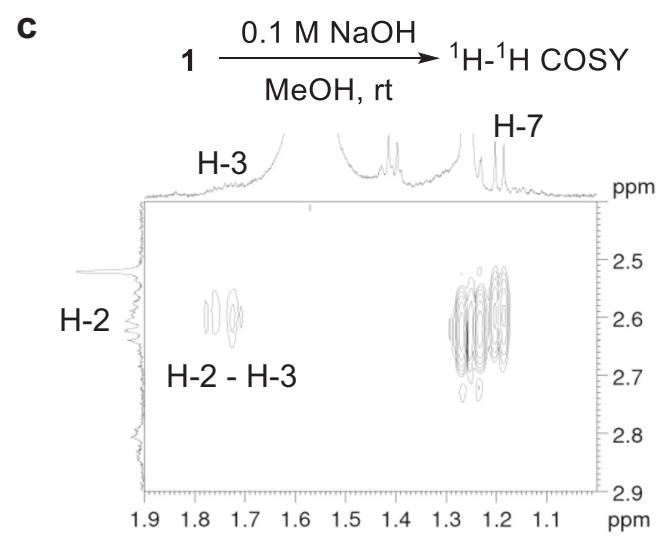

Fig. 4 Determining the configurations of C-9 and C- $4^{\prime}$ in 1. a Structures of penijanthinone $\mathrm{A}$ and $\mathbf{1}$. No NOE correlation was observed between $\mathrm{H}_{3}-16$ and $\mathrm{H}_{3}-17$ in either compound. b Comparing the chemical shift of the $\mathrm{C}-3^{\prime}$ protons in $\mathbf{1}$ with those of the corresponding protons in $(2 R, 4 S)$-2,4-dimethylhexanoic acid and $(2 S, 4 S)$-2,4-dimethylhexanoic acid [17]. The difference in the chemical shifts $(\Delta \delta)$ of the $\mathrm{C}-3^{\prime}$ geminal protons was $0.58 \mathrm{ppm} . \mathrm{c}^{1} \mathrm{H}-{ }^{1} \mathrm{H}$ COSY spectrum of dimethylhexanoic acid obtained by the hydrolysis of $\mathbf{1}$
Corp.) and reported in wavenumbers $\left(\mathrm{cm}^{-1}\right) .{ }^{1} \mathrm{H}$ and ${ }^{13} \mathrm{C}$ NMR spectra were recorded on a Bruker $400 \mathrm{MHz}$ spectrometer (Avance DRX-400; Bruker, Billerica, MA, USA) in $\mathrm{CDCl}_{3}$ and referenced against TMS and $\mathrm{CDCl}_{3}$, respectively. Chemical shifts are expressed in ppm and coupling constants $(J)$ are expressed in Hz. Mass spectra were obtained on a JEOL JMS-700 high-resolution double-focusing mass spectrometer using fast atom bombardment (FAB), or a Sciex X500R quadrupole time-of-flight (QTOF) high-resolution mass spectrometer using electrospray ionization (ESI). Analytical TLC was performed using precoated silica gel $60 \mathrm{~F}_{254}$ plates (Merck, Darmstadt, Germany). Silica gel 60 N (Kanto Chemical, Tokyo, Japan) was used for silica-gel column chromatography.

\section{Isolating vanitaracin A (1)}

Vanitaracin A was isolated from the culture broth of the fungus Talaromyces sp., as described previously [10].

\section{Vanitaracin A (1)}

ECD $\left(c 1.0 \times 10^{-4}, \mathrm{MeOH}\right) \Delta \varepsilon(\mathrm{nm})-7.9(296),+6.5$ (245); ${ }^{1} \mathrm{H}$ NMR $\left(400 \mathrm{MHz}, \mathrm{CDCl}_{3}\right) \delta 7.06(1 \mathrm{H}, \mathrm{s}, \mathrm{H}-7)$, $6.47(1 \mathrm{H}, \mathrm{brs}, \mathrm{OH}), 4.24(1 \mathrm{H}, \mathrm{m}, \mathrm{H}-2), 3.74(1 \mathrm{H}, \mathrm{dd}, J=$ $4.6,17.8 \mathrm{~Hz}, \mathrm{H}-1), 3.44(1 \mathrm{H}$, brs, $\mathrm{OH}), 3.24(1 \mathrm{H}, \mathrm{m}, \mathrm{H}-4)$, $2.75(1 \mathrm{H}, \mathrm{m}, \mathrm{H}-1), 2.74\left(1 \mathrm{H}, \mathrm{m}, \mathrm{H}-2^{\prime}\right), 2.15(1 \mathrm{H}, \mathrm{m}, \mathrm{H}-3)$, $1.76\left(1 \mathrm{H}, \mathrm{m}, \mathrm{H}-3^{\prime}\right), 1.73(1 \mathrm{H}, \mathrm{m}, \mathrm{H}-3), 1.71(3 \mathrm{H}, \mathrm{s}, \mathrm{H}-16)$, $1.51\left(1 \mathrm{H}, \mathrm{m}, \mathrm{H}-4^{\prime}\right), 1.50$ (3H, s, H-17), $1.41(3 \mathrm{H}, \mathrm{d}, J=7.1$ $\mathrm{Hz}, \mathrm{H}-15), 1.35\left(1 \mathrm{H}, \mathrm{m}, \mathrm{H}-5^{\prime}\right), 1.27(3 \mathrm{H}, \mathrm{d}, J=7.0 \mathrm{~Hz}$, H-7') $1.18\left(1 \mathrm{H}, \mathrm{m}, \mathrm{H}-3^{\prime}\right), 1.16\left(1 \mathrm{H}, \mathrm{m}, \mathrm{H}-5^{\prime}\right), 0.93(3 \mathrm{H}, \mathrm{d}$, $\left.J=6.7 \mathrm{~Hz}, \mathrm{H}-8^{\prime}\right), 0.89\left(3 \mathrm{H}, \mathrm{t}, J=7.4 \mathrm{~Hz}, \mathrm{H}-6^{\prime}\right) ;{ }^{13} \mathrm{C} \mathrm{NMR}$ $\left(100 \mathrm{MHz}, \mathrm{CDCl}_{3}\right) \delta 206.2$ (C-10), 191.7 (C-12), 175.6 (C-1'), 158.7 (C-6), 143.9 (C-8), 138.5 (C-14), 129.2 (C-5), 120.2 (C-13), 110.2 (C-7), 83.3 (C-11), 76.1 (C-9), 66.2 (C-2), 40.8 (C-3'), 37.0 (C-3), 36.4 (C-2'), 36.0 (C-1), 34.9 (C-16), 31.9 (C-4'), 29.3 (C-5'), 27.1 (C-4), 23.2 (C-17), 22.1 (C-15), $19.2\left(\mathrm{C}-8^{\prime}\right), 17.8\left(\mathrm{C}-7^{\prime}\right), 11.1\left(\mathrm{C}-6^{\prime}\right)$.

\section{Methylating vanitaracin A}

$\mathrm{K}_{2} \mathrm{CO}_{3}(4.8 \mathrm{mg})$ and $\mathrm{MeI}(0.2 \mathrm{ml})$ were added to a solution of vanitaracin A $(5.2 \mathrm{mg})$ in acetone $(1 \mathrm{ml})$ and the mixture was stirred at room temperature for $48 \mathrm{~h}$. The reaction mixture was diluted with EtOAc $(20 \mathrm{ml})$ and washed with
Table $1{ }^{13} \mathrm{C}$ NMR data for hexanoate moiety in $\mathbf{1},(2 R, 4 S)$ 2,4-dimethylhexanoic acid, and (2 $S, 4 S)$-2,4-dimethylhexanoic acid in $\mathrm{CDCl}_{3}$

\begin{tabular}{ll} 
Compound & $\delta_{\mathrm{C}}\left(\mathrm{C}-2^{\prime}\right.$ to C-8' or C-2 to C-8) \\
${\text { Vanitaracin }(\mathbf{1})^{\mathrm{a}}}^{\mathrm{a}}$ & $40.8,36.4,31.9,29.3,19.2,17.8,11.1$ \\
$(2 R, 4 S)-2,4-$ dimethylhexanoic acid $^{\mathrm{b}}$ & $40.5,37.3,32.1,29.5,18.8, \underline{16.9}, 11.2$ \\
$(2 S, 4 S)-2,4-$-dimethylhexanoic acid & $40.9,37.5,32.3,29.5,19.0, \underline{17.9}, 11.1$ \\
\hline
\end{tabular}

${ }^{\mathrm{a}}$ Measured in $\mathrm{CDCl}_{3}$.

${ }^{\mathrm{b}}$ Reported data measured in $\mathrm{CDCl}_{3}$ [17]. 
$\mathrm{H}_{2} \mathrm{O}(3 \times 10 \mathrm{ml})$. The crude product was purified by silicagel column chromatography with hexane/EtOAc as the eluent $(4: 1 \rightarrow 0: 1)$ to give methyl ether $2(2.6 \mathrm{mg}, 48 \%)$.

\section{Methyl ether 2}

$[\alpha]^{18}{ }_{\mathrm{D}}-71\left(c \quad 0.12, \mathrm{CHCl}_{3}\right) ; \mathrm{UV} \lambda^{\mathrm{MeOH}}{ }_{\max } \mathrm{nm}(\varepsilon) 285$ (10,000), 217 (13,000), $204(14,000)$; IR $\nu_{\max }$ (film) $\mathrm{cm}^{-1}$ 3462, 2961, 2929, 2875, 1733, 1699, 1585, 1460, 1273, 1105, 1034; HRMS (FAB) $\mathrm{m} / \mathrm{z} 461.2537[\mathrm{M}+\mathrm{H}]^{+}$(calcd. for $\left.\mathrm{C}_{26} \mathrm{H}_{27} \mathrm{O}_{7}, 461.2539\right) ;{ }^{1} \mathrm{H} \mathrm{NMR}\left(400 \mathrm{MHz}, \mathrm{CDCl}_{3}\right) \delta 7.16$ $(1 \mathrm{H}, \mathrm{s}), 4.24(1 \mathrm{H}, \mathrm{m}), 3.96(3 \mathrm{H}, \mathrm{s}), 3.76(1 \mathrm{H}, \mathrm{dd}, J=4.4$, $17.5 \mathrm{~Hz}), 3.41(1 \mathrm{H}, \mathrm{brs}), 3.28(1 \mathrm{H}, \mathrm{m}), 2.77-2.69(2 \mathrm{H}, \mathrm{m})$, $2.13(1 \mathrm{H}, \mathrm{m}), 1.81-1.71(1 \mathrm{H}, \mathrm{m}), 1.73(3 \mathrm{H}, \mathrm{s}), 1.50(3 \mathrm{H}, \mathrm{s})$, $1.50(1 \mathrm{H}, \mathrm{m}), 1.37(3 \mathrm{H}, \mathrm{d}, J=7.0 \mathrm{~Hz}), 1.34-1.26(2 \mathrm{H}, \mathrm{m})$, $1.27(3 \mathrm{H}, \mathrm{d}, J=7.0 \mathrm{~Hz}), 1.21-1.13(2 \mathrm{H}, \mathrm{m}), 0.93(3 \mathrm{H}, \mathrm{d}, J=$ $6.6 \mathrm{~Hz}) 0.89(3 \mathrm{H}, \mathrm{t}, J=7.4 \mathrm{~Hz}) ;{ }^{13} \mathrm{C}$ NMR $(100 \mathrm{MHz}$, $\left.\mathrm{CDCl}_{3}\right) \delta$ 206.5, 191.8, 175.5, 161.6, 144.2, 137.2, 130.9, 120.3, 104.8, 83.2, 76.3, 66.1, 55.6, 40.8, 37.0, 36.4, 35.9, $35.5,31.9,29.4,27.0,23.4,22.4,19.2,17.9,11.1$.

\section{The (R)- and (S)-MTPA esters of methyl ether 2}

Triethylamine (0.01 ml), DMAP $(0.5 \mathrm{mg})$, and $(R)$-MTPACl $(0.01 \mathrm{ml})$ were added to a solution of $\mathbf{2}(2.0 \mathrm{mg})$ in $\mathrm{CH}_{2} \mathrm{Cl}_{2}$ $(1.0 \mathrm{ml})$, and the mixture was stirred at room temperature for $1 \mathrm{~h}$. The reaction mixture was diluted with EtOAc (20 $\mathrm{ml})$ and washed with $\mathrm{H}_{2} \mathrm{O}(3 \times 10 \mathrm{ml})$. The crude product was purified by silica-gel column chromatography using hexane/EtOAc as the eluent $(4: 1 \rightarrow 1: 1)$ to afford $(S)$ MTPA ester 3a $(2.2 \mathrm{mg}, 75 \%)$. ( $R$ )-MTPA ester $3 \mathbf{b}$ was prepared in a similar manner using $(S)$-MTPACl.

\section{(S)-MTPA ester 3a}

HRMS (ESI) $m / z \quad 677.2933 \quad[\mathrm{M}+\mathrm{H}]^{+} \quad$ (calcd. for $\left.\mathrm{C}_{36} \mathrm{H}_{44} \mathrm{~F}_{3} \mathrm{O}_{9}, 677.2932\right) ;{ }^{1} \mathrm{H}$ NMR (400 MHz, $\left.\mathrm{CDCl}_{3}\right) \delta$ 7.50-7.48 (2H, m, aromatic signals of MTPA), 7.38-7.32 $(3 \mathrm{H}, \mathrm{m}$, aromatic signals of MTPA), $7.17(1 \mathrm{H}, \mathrm{s}, \mathrm{H}-7), 5.62$ $(1 \mathrm{H}, \mathrm{m}, \mathrm{H}-2), 3.94(3 \mathrm{H}, \mathrm{s}, \mathrm{OMe}), 3.66(1 \mathrm{H}, \mathrm{dd}, J=5.2$, 18.9, Hz, H-1), $3.42(3 \mathrm{H}, \mathrm{s}$, OMe of MTPA), $3.25(1 \mathrm{H}, \mathrm{m}$, $\mathrm{H}-4), 3.04(1 \mathrm{H}, \mathrm{m}, \mathrm{H}-1), 2.75\left(1 \mathrm{H}, \mathrm{m}, \mathrm{H}-2^{\prime}\right), 2.10(1 \mathrm{H}, \mathrm{m}$, H-3), $1.90(1 \mathrm{H}, \mathrm{m}, \mathrm{H}-3), 1.77$ (1H, m, H-3'), $1.72(3 \mathrm{H}, \mathrm{s}, \mathrm{H}-$ 16), 1.56-1.45 (1H, m, H-4'), 1.42 (3H, s, H-17), 1.40-1.30 $\left(1 \mathrm{H}, \mathrm{m}, \mathrm{H}-5^{\prime}\right), 1.27\left(3 \mathrm{H}, \mathrm{d}, J=7.0 \mathrm{~Hz}, \mathrm{H}-7^{\prime}\right), 1.23-1.12(2 \mathrm{H}$, $\mathrm{m}, \mathrm{H}-3^{\prime}$ and $\left.\mathrm{H}-5^{\prime}\right), 1.00(3 \mathrm{H}, \mathrm{d}, J=7.1 \mathrm{~Hz}, \mathrm{H}-15), 0.94(3 \mathrm{H}$, d, $\left.J=6.6 \mathrm{~Hz}, \mathrm{H}-8^{\prime}\right), 0.90\left(3 \mathrm{H}, \mathrm{t}, J=7.4 \mathrm{~Hz}, \mathrm{H}-6^{\prime}\right)$.

\section{(R)-MTPA ester $3 b$}

HRMS (FAB) $m / z \quad 677.2935 \quad[\mathrm{M}+\mathrm{H}]^{+} \quad$ (calcd. for $\left.\mathrm{C}_{36} \mathrm{H}_{44} \mathrm{~F}_{3} \mathrm{O}_{9}, 677.2937\right) ;{ }^{1} \mathrm{H}$ NMR $\left(400 \mathrm{MHz}, \mathrm{CDCl}_{3}\right) \delta$
7.47-7.45 $(2 \mathrm{H}, \mathrm{m}$, aromatic signals of MTPA), 7.35-7.33 $(3 \mathrm{H}, \mathrm{m}$, aromatic signals of MTPA), $7.15(1 \mathrm{H}, \mathrm{s}, \mathrm{H}-7), 5.68$ $(1 \mathrm{H}, \mathrm{m}, \mathrm{H}-2), 3.94(3 \mathrm{H}, \mathrm{s}, \mathrm{OMe}), 3.61(1 \mathrm{H}, \mathrm{dd}, J=4.8$, $19.3 \mathrm{~Hz}, \mathrm{H}-1), 3.43(3 \mathrm{H}, \mathrm{s}, \mathrm{OMe}$ of MTPA), $3.29(1 \mathrm{H}, \mathrm{m}$, H-4), $2.91(1 \mathrm{H}, \mathrm{m}, \mathrm{H}-1), 2.74\left(1 \mathrm{H}, \mathrm{m}, \mathrm{H}-2^{\prime}\right), 2.16(1 \mathrm{H}, \mathrm{m}$, H-3), $2.00(1 \mathrm{H}, \mathrm{m}, \mathrm{H}-3), 1.78\left(1 \mathrm{H}, \mathrm{m}, \mathrm{H}-3^{\prime}\right), 1.71(3 \mathrm{H}, \mathrm{s}, \mathrm{H}-$ $16,1.56-1.47\left(1 \mathrm{H}, \mathrm{m}, \mathrm{H}-4^{\prime}\right), 1.39-1.30\left(1 \mathrm{H}, \mathrm{m}, \mathrm{H}-5^{\prime}\right), 1.35$ $(3 \mathrm{H}, \mathrm{s}, \mathrm{H}-17), 1.27\left(3 \mathrm{H}, \mathrm{d}, J=7.1 \mathrm{~Hz}, \mathrm{H}-7^{\prime}\right), 1.24-1.14(2 \mathrm{H}$, $\mathrm{m}, \mathrm{H}-3^{\prime}$ and $\left.\mathrm{H}^{-5} 5^{\prime}\right), 1.15(3 \mathrm{H}, \mathrm{d}, J=7.1 \mathrm{~Hz}, \mathrm{H}-15), 0.94(3 \mathrm{H}$, d, $\left.J=6.6 \mathrm{~Hz}, \mathrm{H}-8^{\prime}\right), 0.90\left(3 \mathrm{H}, \mathrm{t}, J=7.4 \mathrm{~Hz}, \mathrm{H}-6^{\prime}\right)$.

\section{Structural analysis of vanitaracin A (1) using the crystalline sponge method}

Crystalline sponge analysis was conducted by Mitsui Chemical Analysis \& Consulting Service, Inc. (Chiba, Japan) as described previously $[14,15]$. Briefly, a single crystal of the porous $\left[\left(\mathrm{ZnI}_{2}\right)_{3}(\mathrm{tpt})_{2}(\text { solvent })_{\mathrm{x}}\right]_{\mathrm{n}}$ complex (crystalline sponge, tpt, tris(4-pyridyl)-1,3,5-triazine) immersed in $n$ hexane $(45 \mu \mathrm{l})$ in a vial was treated with a chloroform solution of $1(1 \mu \mathrm{l} ; 1 \mu \mathrm{g} / \mu \mathrm{l})$ for $18 \mathrm{~h}$ at $50^{\circ} \mathrm{C}$ to enable the uptake of 1 into the pores of the crystalline sponge. Singlecrystal X-ray diffractometry (Bruker AXS D8 VENTURE) was performed using a $\mathrm{Cu} \mathrm{K} \alpha \mathrm{X}$-ray source. The sample crystal was cooled to $93 \mathrm{~K}$ using a cold nitrogen stream.

\section{Crystallographic data for 1}

$\mathrm{C}_{84.50} \mathrm{H}_{58} \mathrm{I}_{12} \mathrm{~N}_{24} \mathrm{O}_{3} \mathrm{Zn}_{6}, \mathrm{M}=3372.57$, monoclinic $C 2$, $a$ $=34.3218(17) \AA, b=15.0772(6) \AA, c=28.5217(16) \AA$, $\beta=98.063(4)^{\circ}, V=14613.4(12) \AA^{3}, Z=4, G o F=1.039$, $R_{1}=0.1067, w R_{2}=0.3263$. Flack parameter (Parsons' method): 0.329(7).

Crystallographic data were refined after determining the configurations of all stereogenic centers. The crystallographic information file (CIF) has been deposited with the Cambridge Crystallographic Data Center (2114744).

\section{Hydrolysis of 1}

$\mathrm{NaOH}(0.2 \mathrm{M}, 200 \mu \mathrm{l})$ was added to a solution of $\mathbf{1}$ (2.3 $\mathrm{mg})$ in $\mathrm{MeOH}(500 \mu \mathrm{l})$ and the mixture was stirred at room temperature for $3 \mathrm{~h}$. The $\mathrm{MeOH}$ in the reaction mixture was removed under a stream of nitrogen gas, and the aqueous solution was washed with EtOAc. The aqueous layer was acidified with $0.1 \mathrm{M} \mathrm{HCl}$ to $\mathrm{pH} 2-3$ and then extracted with EtOAc $(3 \times)$. The EtOAc layers were combined and the solvent was removed under a stream of nitrogen gas. The presence of dimethylhexanoic acid was confirmed by ESI-MS (Fig. S9). The crude extract was dissolved in $\mathrm{CDCl}_{3}$ and subjected to ${ }^{1} \mathrm{H}-{ }^{1} \mathrm{H}$ COSY spectroscopy (Fig. S10). 
Acknowledgements We thank Ms. Ai Takase and Mr. Norihiro Nasu (Mitsui Chemical Analysis \& Consulting Service, Inc.) for their crystalline sponge analysis support, and Dr. Tsuneomi Kawasaki (Tokyo University of Science) for his ECD analysis support. We acknowledge the support of Dr. Yayoi Yoshimura (Tokyo University of Science) for the mass spectrometry measurements. This work was supported by a Ministry of Education, Culture, Sports, Science, and Technology supported program for the Private University Research Branding Project, 2016-2020, grants-inaid from the Japan Society for the Promotion of Science (KAKENHI 18K05343, 20H03499, and 21K05299), Program for Basic and Clinical Research on Hepatitis (JP21fk0310114, JP21fk0310103, JP21fk0310101, JP21jm0210068, JP20fk0210036) from the Japan Agency for Medical Research and Development (AMED), and the Center for Human and Animal Symbiosis Science, Azabu University.

\section{Compliance with ethical standards}

Conflict of interest The authors declare no competing interests.

Publisher's note Springer Nature remains neutral with regard to jurisdictional claims in published maps and institutional affiliations.

\section{References}

1. World Health Organization. 2020. Hepatitis B. https://www.who.int/ news-room/fact-sheets/detail/hepatitis-B. Accessed August 2021.

2. Block TM, Alter H, Brown N, Brownstein A, Brosgart C, Chang $\mathrm{KM}$, et al. Research priorities for the discovery of a cure for chronic hepatitis B: report of a workshop. Antivir Res. 2018;150:93-100.

3. Levrero M, Subic M, Villeret F, Zoulim F. Perspectives and limitations for nucleo(T)side analogs in future HBV therapies. Curr Opin Virol. 2018;30:80-9.

4. Tenney DJ, Levine SM, Rose RE, Walsh AW, Weinheimer SP, Discotto L, et al. Clinical emergence of entecavir-resistant Hepatitis B virus requires additional substitutions in virus already resistant to lamivudine. Antimicrob Agents Chemother. 2004;48:3498-507.

5. Lok AS. Combination nucleos(T)Ide analogue as initial treatment for chronic hepatitis b: have we put this to rest? Hepatology. 2013;58:483-5.

6. Zoulim F, Locarnini S. Management of treatment failure in chronic Hepatitis B. J Hepatol 2012;56:112-22.

7. Nakajima S, Watashi K, Ohashi H, Kamisuki S, Izaguirre-Carbonell $\mathrm{J}$, Kwon AT, et al. Fungus-derived neoechinulin $\mathrm{b}$ as a novel antagonist of liver $\mathrm{X}$ receptor, identified by chemical genetics using a Hepatitis C Virus cell culture system. J Virol. 2016;90:9058-74.

8. Nakajima S, Watashi K, Kamisuki S, Tsukuda S, Takemoto K, Matsuda M, et al. Specific inhibition of hepatitis $\mathrm{C}$ virus entry into host hepatocytes by fungi-derived sulochrin and its derivatives. Biochem Biophys Res Commun. 2013;440:515-20.

9. Nishikori S, Takemoto K, Kamisuki S, Nakajima S, Kuramochi K, Tsukuda S, et al. Anti-Hepatitis C virus natural product from a fungus, penicillium herquei. J Nat Prod. 2016;79:442-6.

10. Matsunaga H, Kamisuki S, Kaneko M, Yamaguchi Y, Takeuchi $\mathrm{T}$, Watashi $\mathrm{K}$, et al. Isolation and structure of Vanitaracin A, a novel anti-hepatitis B virus compound from talaromyces Sp. Bioorg Med Chem Lett. 2015;25:4325-8.

11. Kanno K, Tsurukawa Y, Kamisuki S, Shibasaki H, Iguchi K, Murakami $\mathrm{H}$, et al. Novel neuroprotective hydroquinones with a vinyl alkyne from the fungus, pestalotiopsis microspora. J Antibiot (Tokyo). 2019;72:793-9.

12. Murakami H, Murakami-Kawai M, Kamisuki S, Hisanobu S, Tsurukawa Y, Uchiyama J, et al. Specific antiviral effect of violaceoid E on bovine leukemia virus. Virology. 2021;562:1-8.

13. Kaneko M, Watashi K, Kamisuki S, Matsunaga H, Iwamoto M, Kawai F, et al. A novel tricyclic polyketide, vanitaracin a, specifically inhibits the entry of hepatitis B and D viruses by targeting sodium taurocholate cotransporting polypeptide. J Virol. 2015;89:11945-53.

14. Inokuma Y, Yoshioka S, Ariyoshi J, Arai T, Hitora Y, Takada K, et al. $\mathrm{X}$-ray analysis on the nanogram to microgram scale using porous complexes. Nature. 2013;495:461-6.

15. Inokuma Y, Yoshioka S, Ariyoshi J, Arai T, Fujita M. Preparation and guest-uptake protocol for a porous complex useful for 'crystal-free' crystallography. Nat Protoc. 2014;9:246-52.

16. Chen M, Zheng YY, Chen ZQ, Shen NX, Shen L, Zhang FM, et al. $\mathrm{NaBr}$-induced production of brominated azaphilones and related tricyclic polyketides by the marine-derived fungus penicillium janthinellum HK1-6. J Nat Prod. 2019;82:368-74.

17. Myers AG, Yang BH, Chen H, McKinstry L, Kopecky DJ, Gleason JL. Pseudoephedrine as a practical chiral auxiliary for the synthesis of highly enantiomerically enriched carboxylic acids, alcohols, aldehydes, and ketones. J Am Chem Soc. 1997;119:6496-511.

18. Schmidt Y, Breit B. Direct assignment of the relative configuration in 1,3,n-methyl-branched carbon chains by ${ }^{1} \mathrm{H}$ NMR spectroscopy. Org Lett 2010;12:2218-21.

19. Kersten RD, Lee S, Fujita D, Pluskal T, Kram S, Smith JE, et al. A red algal bourbonane sesquiterpene synthase defined by microgram-scale NMR-coupled crystalline sponge X-ray diffraction analysis. J Am Chem Soc. 2017;139:16838-44.

20. Kai K, Sogame M, Sakurai F, Nasu N, Fujita M. Collimonins A-D, unstable polyynes with antifungal or pigmentation activities from the fungus-feeding bacterium collimonas fungivorans Ter331. Org Lett. 2018;20:3536-40.

21. Ariefta NR, Azim M, Aboshi T, Koseki T, Taniguchi Y, Fujita M, et al. Colletofurans A-E, 1-Octyl-1,3-dihydroisobenzofuran derivatives from colletotrichum boninense AM-12-2. Org Lett. 2020;22:3161-5. 